\title{
Why the Successful Assassin Is More Wicked than the Unsuccessful One
}

\author{
Leo Katz†
}

Six floors up and 130 metres away the Jackal held the rifle very steady and squinted down the telescopic sight. He could see the features quite clearly, the brow shaded by the peak of the kepi, the peering eyes, the prow-like nose. He saw the raised saluting hand come down from the peak of the cap, the crossed wires of the sight were spotted on the exposed temple. Softly, gently, he squeezed the trigger....

A split second later he was staring down into the station forecourt as if he could not believe his eyes. Before the bullet had passed out of the end of the barrel, the President of France had snapped his head forward without warning. As the assassin watched in disbelief, he solemnly planted a kiss on each cheek of the man in front of him. As he himself was a foot taller, he had had to bend forward and down to give the traditional kiss of congratulation that is habitual among the French and certain other nations, but which baffles Anglo-Saxons.

It was later established that the bullet had passed a fraction of an inch behind the moving head.

Frederick Forsyth, The Day of the Jackal ${ }^{1}$

The assassin takes aim and fires. If he hits his mark, it is murder; if his target eludes the fatal bullet, it is a mere atteinpt, punishable at only a fraction of the sentence for murder. How utterly and indefensibly bizarre. As Sandy Kadish puts it, "Suppose... the law provided that any crime committed during the night of a half-1noon may not be punished with more

Copyright (c) 2000 California Law Review, Inc. California Law Review, Incorporated (CLR) is a California nonprofit corporation. CLR and the authors are solely responsible for the content of their publications.

$\dagger \quad$ Professor of Law, University of Pennsylvania. Thanks are due my fellow symposiasts for their probing questions. Special thanks are owed Paul Robinson and Claire Finkelstein for greatly helping, nay, forcing me to sharpen the argument.

1. FREDERICK ForsYTH, THE DAY OF THE JACKAL 354-55 (Bantam Books, 1980) (1971). 
than one-half the punishment appropriate on all other occasions." An absurd idea and yet, asks Kadish, is this not exactly what the law of attempt comes to?

My aim in this essay is to pick up the gauntlet Kadish throws down in The Criminal Law and the Luck of the Draw, ${ }^{3}$ to make the moral case for punishing completed offenses more severely than attempts. When 1 say "moral case," I mean a nonconsequentialist justification of the law of attempt. I suspect most people would agree that with the right kind of background assumptions, a law-and-economics story could be told to make the attempt doctrine look efficient. The real challenge is to tell a story from a deontological point of view. That is no mere academic exercise, since the prevailing sense among criminal law scholars is that the criminal law is the one area of the law in which the nonconsequentialist parts of our everyday moral intuitions almost (almost!) indisputably hold sway. ${ }^{4}$ Alas, from the vantage point of everyday morality, the idea that the assassin is less wicked if his bullet misses than if it hits its mark does indeed appear strange in the extreme. "Would the father who stabbed his son deserve less punishment if a skillful doctor had been available to save the son's life?" asks Sandy Kadish, "Would the Russian Roulette player deserve less punishment if the bullet happened to be in another chamber when he fired?"s Just so, I am going to argue, just so.

Why not just admit that the law of attempt makes no sense? Why not just say that it deserves abolition, or maybe toleration, but hardly endorsement? Because despite its seeming nonsensicality, there is a strong and deep intuition that "outcome luck" (as the philosophers like to call it) matters. To get a sense of the strength and the depth of that intuition, consider for a moment a famous thought experiment that Robert Nozick proposed in Anarchy, State and Utopia:

Suppose there were an experience machine that would give you any experience you desired. Superduper neuropsychologists could stimulate your brain so that you would think and feel you were writing a great novel, or making a friend, or reading an interesting book. All the time you would be floating in a tank, with electrodes attached to your brain. Should you plug into this machine for life, preprogramming your life's experience?

2. Sanford Kadish, The Criminal Law and the Luck of the Draw, 84 J. CRim. L. \& CRImINology 679, 680 (1994). For a good anthology on the problem of moral luck more generally, see Moral LucK (Daniel Statman ed., 1993).

3. Kadish, supra note 2 .

4. When I say nonconsequentialist I mean to refer to, broadly speaking, any view that does not seek to justify legal rules in terms of their maximization of some external good. Retributivism, deontology, libertarianism, or rights-theory are the names by which several greatly overlapping versions of such a view go.

5. Kadish, supra note 2, at 688 .

6. Robert NOZICK, ANARCHY, State AND UtOPIA 42 (1974). 
Nozick's answer is, of course, no. More matters to us, he concludes, than how our lives "feel from the inside." We want to do certain things, and be certain things, in addition to having the experience of doing and being. There are two ways in which you could have the thrill of leading men into battle and valiantly vanquishing the enemy. You could do it by hooking up to a suitably preprogrammed experience machine; or you could do it for real. The former is as thrilling as, and much safer than, the latter. Yet, says Nozick, most of us choose the latter.

Our intuitions about Nozick's experience machine allow us to appreciate the profound hold that outcome luck has on us. Nozick is, of course, thinking primarily about the good things in life. But what he says should hold for the bad things as well. Consider the following two ways in which I might be led to feel guilty about committing a murder. Alternative \#1: while I am hooked up to Nozick's experience machine, I commit a murder. As it turns out, it is not a real murder, just something that happens on a video screen, so to speak. Alternative \#2: in real life, I commit a murder. Does it make sense for me to feel guiltier about the latter than the former? Well, if I feel prouder of my achievements as a real platoon leader than as an imaginary one, then it seems I should feel guiltier about my achievements as a real murderer than as an imaginary one. But feeling guilty, as opposed to regretful, means that I think I behaved worse when I killed for real than when I merely imagined I was killing. And that suggests that the Jackal who misses really is less wicked than the Jackal who hits. $^{\text {? }}$

Nozick's thought experiment is suggestive; but what can one say by way of argument to back up the law of attempt? In this essay I will pursue two different lines of argument. In Part I, I recapitulate and elaborate on certain previously tried strategies for making out the moral case for the law of attempt. I call these the "Why-Luck-Is-Like-Water" strategies, because they all rely on the idea that luck is a ubiquitous and indispensable feature of our moral thinking. I conclude Part I with a surmise as to why those strategies have failed to persuade the "Iuck-skeptic." Part II strikes out in an entirely different direction. In it, I try to approach my subject from a rather unexpected and unpromising-looking angle, hoping to catch my prey, as it were, from behind. I have called this, because of its similarity to that wonderfully fallacious argument mothers used to use to get their recalcitrant children to eat, the "Think-of-Those-Poor-Starving-Children" strategy. It will involve comparing the successful and the unsuccessful assassm to a seemingly irrelevant third kind of miscreant, who, I will argue, clearly is less blameworthy than the successful assassin and more blameworthy

7. For a fuller presentation of this argument, see LEo KATZ, ILL-GOTTEN GAINS: EvASION, BlackMail, Fraud, aNd Kindred Puzzles of the LaW 73-83, 224 (1996). 
than the unsuccessful one. By implication, there must then be a moral difference between the two kinds of assassin.

My general method is going to be the prevailing one in applied ethics, the method John Rawls dubbed the search for a reflective equilibriuin. 1 will try to show the greater wickedness of the successful assassin to follow froin other dearly held moral intuitions that no one would want to do without.

I

THE "WhY-LUCK-Is-LiKe-WATER" STRATEgIES

We tolerate luck in many domains of our moral life: Like water, luck pervades everything. Each of these domains in which luck crops up gives rise to a different strategy for making an argument in behalf of the "lucky" assassin - the assassin who misses. Let us see how those arguments would go.

\section{A. The Argument from Criminal Law Doctrine}

The first of the Why-Luck-Is-Like-Water strategies is based on the ubiquity of luck throughout our criminal law. The law of attempts is hardly the only place in which luck plays a prominent role. There are many doctrines in which it figures far more prominently, namely those making use of strict liability elements: the felony-murder rule; the ignorance of law principle; the part of the omission doctrine that imposes a special duty to aid on those who created a peril, even if they acted without any fault; all those strict liability regulatory crimes; inany statutory rape laws. Then there are the doctrines that depend more subtly on luck than either strict liability offenses or the law of attempt: the version of the impossibility defense that acquits the defendant who shoots at a tree stump thinking it is a person; the version of the necessity doctrine that acquits the defendant who unreasonably but correctly disobeys a police order to save the life of a friend; the version of complicity law that acquits the defendant who tries to hire an assassin, but ends up making contact with an undercover policeman. All these depend on luck. If we accept luck here, why not in the law of attempts?

Alas, the luck-skeptic is not much moved by this argument. As Kadish explains in Luck of the Draw, he does not like the aforementioned doctrines any better than he likes the law of attempt. ${ }^{8} \mathrm{He}$ certainly does not think of them as models of sound moral intuition. He is willing to desist reforming them away, just because that would seem like too radical an undertaking. But that does not mean he endorses them.

8. See Kadish, supra note 2, at 699-702. 


\section{B. The Argument from Moral Intuitions About Outcome Luck}

The second of the Why-Luck-Is-Like-Water strategies is based on the fact that in case after special case in which someone tries to do harm we feel radically differently if he brings such harm about than if he does not. Do all those raw intuitions not add up to a significant mountain of evidence for the moral validity of the law of attempts? Is that not how we generally justify a moral principle - by appealing to a mass of more particular moral judgments that square with it? Some luck-skeptics might deny that they have those feelings about particular cases. But they are deceiving themselves. Just look at Paul Robinson's and John Darley's pioneering exploration of popular sentiment on our criminal law doctrines, and you will have little doubt that at a gut IeveI people pIace greater blame on the successful wrongdoer than the unsuccessful one. ${ }^{9}$

Nevertheless there is, as Michael Moore notes, good reason to be wary of those intuitions. They are likely to be corrupted by the fact that most of us know about the law of attempt. ${ }^{10}$ We know that the unsuccessful criminal is punished less than the successful one, and that colors our responses. We are a bit in the position of the economics graduate student who wants to find out whether people who encounter reaI-life prisoner's dilemmas do or do not cooperate. He would do well to steer clear of surveying his fellow economics graduate students. Having heard the prisoner's dilemma explained to them inakes them feel rather differently about cooperation than they would otherwise: Witness the fact that in experiments the man in the street tends to cooperate, but the typical economics graduate student does not. "More people know about the law of attempt than about the prisoner's dilemma. That makes their intuitive judgments in the matter highly untrustworthy.

\section{A Variation of the Argument: Remedial Efforts and Remorse}

One might try to salvage the appeal to our raw, gut-level intuitions about outcome luck by focusing on cases less likely to be contaminated by knowledge of the law of attempt. Certain cases involving extremely remorseful wrongdoers might fit that bill. Consider the followimg two scenarios:

Case 1. D1 has planted a bomb that is about to explode and result in the death of several people. He starts to feel enormous remorse and tries to undo his own handiwork by going into the building

9. See Paul H. Robinson \& John M. Darley, Justice, Liability, and Blame: Community Views and the Criminal Law 13-51 (1995).

10. See Michael Moore, The Independent Moral Significance of Wrongdoing, in Placing Blame 192-247 (1997).

11. See Robert H. Frank, Choosing the Right Pond: Human Behavior and the Quest FOR STATUS (1985). 
where he planted the bomb in order to retrieve it. He is likely to be badly injured in the process. This indeed happens. No one else is injured in the bomb blast.

Case 2. D2 has murdered several people by causing a bomb to explode. Afterwards he feels enormous remorse, so much so that he makes efforts to actually mutilate himself in self-punishment, although the authorities manage to stop him.

Whether or not you think that an attempt is as bad as its completed counterpart, you will be inclined to give enormous credit to D1 for trying, at great cost to himself, to undo his crime. Perhaps you do not give him so much credit as to acquit him of all wrongdoing, but I find it hard to believe that you would not consider his conduct highly mitigating. You are likely to feel very differently about D2. It is true, he feels remorse to the point of not merely self-flagellation, but self-mutilation. But I doubt that makes us think that his blameworthiness and his merited punishment are diminished all that much. Yet the difference in our reactions solely reflects outcome luck. To be sure, you might try to argue that it reflects something else. You might argue, for instance, that D2's desire for self-injury is not intended to help anyone, whereas D1's effort to retrieve the bomb is. The problem with this argument is that D2 surely wishes that his efforts at self-mutilation could help his victims. The fact that they do not is purely a matter of outcome luck.

Some of the luck-skeptics might be moved by this argument. But many, I fear, will not. Most likely, they will argue that their feelings about my two cases are ambiguous, and that after reflecting on them for a while, they incline to the conclusion that in fact D1 and D2 are equally wicked: Both deserve great blame for planting the bomb; both deserve some credit for the remorse they feel. D1, however, deserves no more credit than $\mathrm{D} 2$, since his ability to avert the explosion is purely a matter of outcome luck.

\section{Another Variation of the Argument: The Appeal to Praise}

Another way to try to salvage the appeal to raw intuitions about outcome luck is to think about the role it plays outside the realm of blame: Consider the role it plays in the realm of praise. Many people find outcome luck much easier to accept when thinking about praise rather than blame. They have no trouble awarding Frederick Banting the Nobel Prize in Medicine despite the fact that his discovery of insulin resulted from a "wrongly conceived, wrongly conducted, and wrongly interpreted series of experiments,"12 or, in the words of a another critic, that it "resulted from a stumble into the right road where it crossed the course laid down by faulty

12. Alexander Kohn, Fortune or Failure: Missed Opportunities and Chance DiscoverIEs 156 (1989) (citation omitted). 
conception." 13 They do not think Banting's harder-working, more meticulous, and more ingenious counterparts in some other lab who had the ill fortune of not coming across insulin are more deserving of the prize. Indeed the role we allow luck to play when it comes to praise can be quite extreme. A well-established principle of credit-giving in science holds, "When the discoverer of a certain fact hears that another scholar has found a notable consequence of it, if this improvement has required some effort, the former will consider it not a failure but a success: he has the right to claim his part in the new discovery."14 Newton's famous remark, "If I have seen farther than others, it is because I have stood on the shoulders of giants," expresses the same thought. ${ }^{15}$ Under this principle, a discoverer gets praise for a consequence which he did not intend and had not the slightest inkling he was bringing about. Well, if outconie luck holds such sway with praise, why not with blame? ${ }^{16}$

Unfortunately, the very fact that we are so tolerant of luck when it conies to praise might suggest to the luck-skeptic that luck just operates differently when it comes to praise. After all, if we transposed the abovequoted principle of credit-giving-the one embodied in the Newton reniark -into the realm of blame, it would require us to say that the person who has committed a bad deed, let us say a killing, which then leads to some further deaths the perpetrator could not foresee, should be punished for those further repercussions. Not even the felony-murder rule would allow that.

\section{The Argument from Moral Intuitions About Other Kinds of Luck (Other, that Is, than Outcome Luck)}

The third, and to my mind most compelling, of the Why-Luck-IsLike-Water strategies appeals to our acceptance of inany other kinds of luck than outcome luck in making moral judgments. Note how this argument is different from the previous one: It appeals not to the pervasiveness of outcome luck, it appeals to the pervasiveness of other kinds of luck. I will explain in a moment what those are.

Consider niore closely the assassin's trajectory. I do not just mean the trajectory of his bullet. I mean the trajectory of his life, from birth up to the moment that he fires his bullet. At every moment in that long trajectory, Michael Moore points out, luck could have intervened to stay his hand.

13. Id.

14. Jacques Hadamard, AN Essay on the Psychology of Invention IN the Mathematical Field 49 (1949).

15. For the history of the phrase and the idea, see Robert K. Merton, ON The Shoulders of GlaNTs (1965). It was that way with Alexander Fleming, the discoverer of penicillin's bacteria-killing powers, who had no idea that penicillin could stay in the body long enough to have medicinal uses. See Gwyn Macfarlane, Alexander Fleming: The Man AND the Myth (1984).

16. For a fuller discussion of luck and praise, see KATZ, supra note 7, at 218-24. 
Luck might have caused him to be brought up to hate violence. (Philosophers call this "character luck.") Luck might have kept him out of temptation's way. (Philosophers call this "opportunity luck.") Luck might have caused him to have a sneezing fit just as he was deciding whether to try to kill. (Philosophers call this "circumstantial luck.") And finally, luck might have caused his bullet to miss its mark-the case of outcome luck.

Luck-skeptics are not much bothered by the intervention of those other kinds of luck. They do not feel bad about treating two people differently who, but for the fact that one was brought up to hate violence and the other to love it, would have led identical lives-they do not much care about "character luck." They do not feel bad about treating two people differently who, but for the fact that one had the good fortune of never encountering temptation whereas the other did, would have had similar destinies-they do not much care about "opportunity luck." They do not feel bad about treating two people differently who, but for the fact that one was distracted from a violent impulse by a last-minute sneezing fit whereas the other was not, would have acted the same-they do not much care about "circumstantial luck." The only thing they feel bad about is treating two people differently who, but for the fact that one's bullet missed its target whereas the other's did not, would be indistinguishable. They simply cannot stomach the influence of outcome luck. But what is so special about outcome luck? If those other kinds of luck are morally acceptable, why not the latter? Why treat these different kinds of luck so asymmetrically? There seems to be no principled difference between them.

But that is an asymmetry the luck-skeptic really does not find very troubling. There is, as he sees it, plenty to distinguish these different kinds of luck. As to the one that it might seem hardest to deal with, "opportunity luck," Sandy Kadish writes:

The settled moral understanding is that what you deserve is a function of what you choose. It may be that you would not have had occasion to make a choice that revealed your badness if you had better luck. Nonetheless, you did make a choice-nobody made you -and it is that choice for which you are blamed. It is a different matter, however, to say that chance occurrences that follow after you have made your choice determine what you deserve, for that is to rest desert upon factors other than what you chose to do. Fortuity prior to choice, therefore, may be accommodated to our notions of just desert; fortuity thereafter cannot. $^{17}$

In other words, there is fortuity and there is fortuity. Not even the staunchest defender of the law of attempt and the acceptability of outcome luck thinks that a father, say, should be held liable for a murder committed

17. Kadish, supra note 2, at 690. 
by his son, just because he is the father. That would be fortuity too. As the luck-skeptic sees it, to make the extent of someone's liability turn on outcome luck is like making it turn on whether his son has committed a crime. That is very different from making it turn on opportunity luck, or character luck, or circumstantial luck, which the luck-skeptic has no problem with.

Where do the foregoing three strategies for defending the role of outcome luck in the law of attempt ultimately leave us? Each of those strategies proceeds by showing the luck-skeptic cases in which he arguably accepts luck of one kind or another and then challenges him to explain why he is so much harder on outcome luck. The luck-skeptic deals with those cases either by distinguishing them (opportunity luck, he insists, really is different from outcome luck) or by saymg that on reflection he thinks luck plays an objectionable role in those cases as well (perhaps, he says, we should not give more credit to the remorseful assassin who manages to deactivate his bomb than to the one who tries but fails). But I suspect the more basic reason the luck-skeptic remains unmoved by those strategies is that they strike him as circular. They appeal to intuitions about luck in order to defend intuitions about luck. Now that does not nuake them circular in any vicious sense: They appeal to different kinds of luck in different kinds of contexts to explain outcome luck in one particular kind of context. Still, our intuitions about any kind of luck are so uncertain, so unstable, so squishy, as to make any argument based on them uncertain, unstable, and squishy.

That suggests that a different kind of strategy might work where those others have failed, a strategy that is based on intuitions having nothing to do with luck. In the next Section I shall offer such an argument.

II

\section{ThE "ThINK-OF-Those-PoOR-STARVING-ChILdREN" STRATEgY}

"Think of those poor starving children in ..." is the wonderfully irrelevant comparison by which mothers seek to persuade their children to finish the food on their plates. The essence of my argunient in this Section will consist of a crucial comparison that at first glance is going to seem equally irrelevant. It is not really, but it has that feel. I will be comparing the relative blanneworthiness of the successful assassin and of a very unusual kind of unsuccessful assassin, who I will show clearly is less wicked than the successful one. I will then show this unusual kind of unsuccessful assassin to be more wicked than the usual kind of unsuccessful assassin. If it is possible to find such a case, then it follows that the ordinary successful assassm really is more wicked than the ordinary unsuccessful one. 


\section{A. The Argument}

The argument I am about to present exploits a paradox I have been thinking about for some time. When I first encountered it, it simply struck me as intrinsically interesting. As time passed, I discovered that I was able to connect it with a variety of seemingly unrelated problems, and that it shed light on issues that had previously struck me as intractable. I have drawn on this paradox, for instance, to explain why ignorance of law is no defense, ${ }^{18}$ or why maliciously provoking someone to attack you so that you can kill him in "self-defense" should be a defense. ${ }^{19}$

I am going to begin by presenting the simplest version of the paradox. In this simple version, I am going to presuppose the validity of the law of attempt (that is, the greater blameworthiness of completed offenses than attempts). Before I can use the paradox to justify the law of attempt, I will have to run the argument again without that presupposition. But that will require me to construct some more artificial versions of it and those are harder to grasp if you have not seen the simple version first.

The simple version of the paradox goes as follows. Larry has poisoned five people, with the intent to kill them. Having done so, he has regrets and would if at all possible like to save them. As it happens, the poison takes effect in a philosophically convenient way: It destroys the kidneys of some people, the lungs of others, the hearts of yet others. In this particular case, it has all but destroyed the lungs of two, the kidneys of another two, and the heart of a fifth. All five could be saved by suitable transplants, but no donors can be found. Larry considers killing a bystander and confiscating his organs to save the five. Is he allowed to do so? No, of course not. The general deontological prohibition against certain kinds of comparatively advantageous tradeoffs would require him to refrain. The fact that Larry precipitated the five victims' predicament does not change that.

But notice what happens to Larry's legal and moral liability on each course of action he imight choose. If he chooses to do the right thing and abstain from killing the one for the sake of the five, he will be guilty of five murders. If he chooses to do the wrong thing, killing the one in order to redeploy his organs to save the five, he is now guilty of only one murder. He may also be guilty of five attempted murders, depending on how the abandonment doctrine is construed. But that is about it. Five murders seems quite a bit worse than one murder and five attempted murders. So by

18. See Leo Katz, Incommensurable Choices and the Problem of Moral Ignorance, 146 U. PA. L. REv. 1465 (1998).

19. See Leo Katz, Form and Substance in Law and Morality, 66 U. CH1. L. REv. 566 (1999). 
doing the wrong thing he could actually end up with a better overall record, an improved moral ledger. ${ }^{20}$

This is an odd result. Just to drive home its oddity, imagine two individuals, Larry and Michael, whose lives have been identical up until the moment each decides to poison five people. They now both find themselves at that fork in the road where they can either let nature take its course and allow their five victims to die, or they can carve up a sixth for the benefit of the five. Suppose God appears to each of them, and they ask him what they should do. He would advise them not to kill the sixth. Suppose Larry decides to disregard God's advice and kill, whereas Michael decides to abstain. Now they arrive at the pearly gates. Who has a better chance of entering? If I am right, Larry does, since he has the better moral record: He only committed one murder and small change, whereas Michael committed five murders. Yet the only reason Larry has a better moral record is that he flouted God's advice, whereas Michael took it. How perverse.

Here is another way of putting the matter. Suppose I told you that Larry and Michael pursued identical paths in parallel universes. They committed the same sins, performed the same good deeds. Then each comes to a fork in the road, indeed the very same fork in the road. One branch of the fork, I tell you, is clearly wrong, one branch is clearly right. Larry chooses to take the wrong path, Michael chooses to take the right path. Who is better? It seems tautologically true that Michael is better than Larry. But that is precisely what my example argues is not true!

Yet another way of highlighting the oddity is to think about the precept that one cannot be blamed for what one could not help doing. This most obviously holds true if it was physically impossible for the agent to do other than he did. We also generally think that the precept prohibits blaming someone for what he could not help doing without being guilty of a gross immorality. To blame him under those circumstances seems like a cruel joke. Yet that is exactly what my paradox suggests we do. When compared to Larry, Michael receives extra blame solely on account of

20. Maybe you are unsure whether five murders are in fact worse than one murder and five attempted murders. Even if you accept the law of attempt, you may be uncertain whether the discount is heavy enough for one murder and five attempts to be better than five murders. If this is how you feel, consider the following variation on my example. Let us assume that Larry poisoned only two people, one of whom is on the verge of dying of poisoned kidneys, the other of poisoned lungs. Larry considers seizing an innocent and ripping out his redundant kidney and lung. Is he entitled to do that? Pretty clearly this too would be an impermissible tradeoff, notwithstanding its utilitarian merits. Still, if he decides to flout the prohibition on such tradeoffs and seizes the innocent, he will be guilty of only two attempted murders and one grievous assault, which is a substantial improvement. (And if we replace the expropriation of bodily organs with the mere expropriation of blood, the imbalance becomes even more extreme: The comparison would then be two murders versus two attempted murders plus an assault of the forced blood-giving variety.) 
something-the deaths of the five-which he could not have averted without committing a gross immorality, the carving up of the one.

It is worth pointing out that nothing in my paradox turns on my choice of that particularly exotic looking impermissible tradeoff, the carving up of an innocent to save five people in need of transplants. All that is required for the paradox to arise is for the agent to have committed an initial wrong and that doing something that would make sense from a consequentialist point of view, but is off limits from a nonconsequentialist point of view, could reverse the course on which he has embarked. Any of the famous impermissible tradeoffs would have done the trick: the judge considering executing an innocent to appease a rabble that will otherwise kill many more innocents, or the policeman debating whether to torture a child to get a terrorist to reveal where he hid a bomb.

Some will be inclined to dismiss the paradox on the following rather persuasive grounds. ${ }^{21}$ Thus far, my argument has presupposed the validity of the law of attempt. But of course many consider the law of attempt highly paradoxical. And it might appear as though it is the paradoxical character of the law of attempt that lies at the root of the paradox I have sketched above. It might appear as though the paradox would not arise without this assumption. Reexamine the paradox on the assumption that attempts are as wicked as completed offenses. On that assumption, what would Larry be guilty of if he tried to poison five people and then carved up a sixth to save the five? He would essentially be guilty of six murders. (His five attempts would count as five murders and his killing of the sixth to save the five would count as a sixth murder.) What would he be guilty of if he did not carve up the sixth person? Five murders. (Because exactly five people have died.) And suddenly the paradox has disappeared. Now Larry's engaging in the forbidden tradeoff (carving up one for the sake of five) really does make him worse than Michael.

But the paradox has only temporarily disappeared. With a little bit of tinkering one can reconstitute it, that is, one can establish that the person who averts the death of five by carving up a sixth is less blameworthy than the one who does not. Moreover, one can do so without making any assumption, one way or the other, as to whether an attempt is more blameworthy than the completed offense. And that had better be so, or else 1 would not be able to use the paradox to justify the law of attempt.

Consider both Larry and Michael at the stage at which they are first getting ready to poison their five victims. Since Larry is going to act a little differently in this new version of the hypothetical, let me rename him Larry Jr. Let us assume that this Larry Jr. from the very outset plans first to poison and thereafter to cure his victims by killing a sixth person and using his organs to save the five. Michael, by contrast, plans simply to poison

21. I owe this objection to Larry Alexander. 
them and leave things there-the same as before. Larry Jr. and Michael both carry out their plans, with no unanticipated, fortuitous developments or changes of mind. Again, let us compare their overall moral ledgers: Larry Jr. still comes out ahead of Michael. In fact Larry Jr.'s edge over Michael is, if anything, more formidable than was Larry's. Larry Jr. cannot now be described as ever having had an intent to kill his five victims. His intent was to kill only one. Michael, by contrast, intended to and did kill five.

Let us focus next, however, on that moment in time when Larry Jr. and Michael each face the possibility of saving their five victims by killing a sixth. It is still true, as it was before, that Michael's choice not to kill the one for the sake of the five is morally superior to Larry Jr.'s choice to kill one for the sake of the five. It is also still true that the only reason Larry Jr.'s overall plan puts him in a better moral position than Michael's is that he was planning to make this immoral choice down the road. The essential paradox survives intact even though we have now removed all elements of fortuity, all residues of moral luck, from the argument.

This is not quite the origmal paradox, but it is close. And if we wanted actually to recreate the original paradox we just need to add one further step to the argument. Consider the situation of Larry who embarks on the poisoning plan intending to behave like Michael (that is, intending to kill five people), but when he has actually poisoned five people, changes his mind and decides to behave like Larry Jr. (that is, to save them by carving up a sixth). His overall conduct is now identical to Larry Jr.'s (he poisons five people and then saves them by carving up a sixth). His state of mind is identical to Michael's up until the moment that he has to decide whether to carve up a sixth. Then, at the last minute, his state of mind switches to that of Larry Jr. In other words, Larry's actions are indistinguishable from Larry Jr.'s, and his state of mind is like Michael's only up until the point where it counts, then it becomes likes Larry Jr.'s. That would suggest that his wickedness is somewhere between Michael's and Larry Jr.'s.

In fact I would argue that it is much closer to Larry Jr.'s than to Michael's. Imagine fleshing out Larry Jr.'s and Larry's behavior in the following way:

Case 1. Larry Jr. cannot decide whether to poison his five victims outright, or whether to save them after he has poisoned them, by carving up a sixth. Seconds before administering the poison, he decides he is going to save them by carving up a sixth.

Case 2. Larry cannot decide whether to poison his five victims outright, or whether to save them after he has poisoned them, by carving up a sixth. Seconds after administering the poison, he decides he is going to save them by carving up a sixth. 
The facts of Case 1 and Case 2 differ minutely. I am inclined to think this means that Larry is not much worse than Larry $\mathrm{Jr} .{ }^{22}$ For my purposes all that I need is that you not judge Larry to be worse than Michael; and I simply do not see how you can.

We are now ready for the argument about luck. I am going to add a new character to our list: Stephen, my version of the assassin whose bullet misses its mark. Compare the following two cases:

Case 1. Larry poisons five people intending to kill them, and having poisoned them, changes his mind and saves them by carving up a sixth. In other words, when it is all over the five victims are alive, even if not exactly better for the experience.

Case 2. Stephen poisons five people intending to kill them, but it turns out the dosage he administered is not strong enough to do the job. (He could administer a second dose and make sure they die, but that seems too difficult and risky, and so he does not.) In other words, when it is all over the five victims are alive and kicking, even if not exactly better for the experience.

Who is worse, Larry or Stephen? Both Larry and Stephen started out trying to kill five people. Both failed in that endeavor. Larry however gets to that outcome-the "nonkilling" of the five-by killing a sixth, whereas Stephen gets to that result by simply not doing anything, that is, by not administering a second dosage of the poison: His poison is just too weak. Stephen is thus clearly better than Larry. We already know Larry is better than (or at least no worse than) Michael. Therefore Stephen is better than Michael. In other words, Stephen, who intends to kill but fails in carrying that crime to completion, is better than Michael, who intends to kill in the identical fashion, under the identical circumstances, for the identical reasons, and who succeeds in doing so. Q.E.D.

Now you may be having second thoughts about one part of my argument: the claim that Larry and Larry Jr. really are equally, or almost equally, blameworthy. Sometimes minute differences can make an enormous difference in ethics. Perhaps this is such a case. Perhaps it really is important that Larry Jr. changes his mind right before injecting the poison and Larry right after doing so. Injecting the poison looks like the most pivotal step in the whole enterprise. Maybe it is a kind of moral watershed, such that the person who changes his mind before crossing it is in a different moral class from the person who changes his mind after crossing it. Perhaps, but I doubt it.

I doubt it because injecting the poison really is only one step in a long process which begins with first thinking about killing the five, continues

22. To be sure, sometimes minute differenees can make an enormous ethical difference, but this does not strike me as such a case. For a fuller discussion of cases in which it does, see Katz, supra note 7 , at $163-69$. 
with thinking about how to accomplish the killing, continues further with inquiring into the whereabouts of some potent poison, continues further yet with purchasing the ingredients for concocting the poison, continues further yet with preparing the poison for injection, and is by no means completed yet when the poison is actually injected, because the process will result in death only if the assassin then desists from doing anything to counteract the effects of the poison (such as killing an innocent bystander to save the five). Anywhere along the line, the assassin might change his mind from merely intending to kill the five to merely intending to poison them but then to save them by killing a sixth. It may well be that the later he changes his mind, the more blameworthy he is. But that increase in blameworthiness is presumably a slow and gradual one: If he changes his mind a little bit later, he is a little bit worse. It is hard to see that there are any moral thresholds in this process, such that if he changes his mind right before them he is radically less blameworthy than if he changes his mind right after them. It may well be that he is a little bit less blameworthy if he changes his mind right before inquiring into the whereabouts of some poison than right after, but only a little bit, not a lot. It may well be that he is a little bit less blameworthy if he changes his mind before concocting the poison, than right after it, but again, only a little bit, not a lot. By the same token it may well be that he is a little bit less blameworthy if he changes his mind right before injecting the poison rather than right after, but again it seems, only a little bit, not a lot. ${ }^{23}$

23. Perhaps I should give this point a rest now, but it is such a crucial one that I will go on a little bit longer. Suppose you are still not sure whether to accept that Larry and Larry Jr. really are pretty much alike in their leveis of blameworthiness. In that case, let me suggest a different way in which you might convince yourself that at least one of the Larries lies between Michael and Stephen. After all, that is all we need in order to demonstrate that Michael and Stephen, the people we are primarily interested in (the successful and the unsuccessful assassin), differ in blameworthiness. This argument is not meant to convince you that Larry and Larry Jr. are equivalent, but only that Larry Jr.'s level of blameworthiness lies between that of Michael and Stephen. It would then follow that Michael and Stephen differ in blameworthiness.

Consider the case of Stephen Jr. He is just like Stephen except that in preparing his poison for injection he runs into a snag. Something prevents him from successfully completing the concoction of the poison: He screws up the chemical reaction, or an iugredient turns out to be missing, or a piece of equipment fails-whatever.

Now compare the level of blameworthiness of Stephen Jr. with that of Stephen: They are nearly identical. Maybe Stephen Jr. is a little better because he got stopped in his tracks a little sooner than Stephen, but it is hard to beheve there is much of a difference between them.

Compare next the blameworthiness of Stephen Jr. and Larry Jr. At the moment of concocting the poison, both Stephen Jr. and Larry Jr. are planning to kill five people. Both end up not being able to implement that plan: Stephen because his concoction process fails; Larry Jr. because he decides after completing the concoction, but before injecting it, to save the five people he plans to inject by killing a sixth. The same powerful intuition that suggested that Stephen is better than Larry suggests that Stephen Jr. is better than Larry Jr. Stephen seemed better than Larry because he got to the same goal as Larry (that of five people not dying) by being frustrated in his designs by some external factor (the carving up of an innocent). Similarly, Stephen Jr. seems better than Larry Jr. because he too is 
Larry Jr. thus may be a little less blameworthy than Larry, but unless he is a whole lot less blameworthy, my argument works. It works because it seems intuitively evident that Michael is substantially worse than Larry Jr., and Stephen is substantially better than Larry. That means that Larry and Larry Jr., being pretty close in blameworthiness to each other, lie between both Michael and Stephen.

Let me summarize my argument briefly. Consider three cases:

Case 1. Assassin A1 poisons five people and they die. (Michael)

Case 2. Assassin A2 poisons five people. Then he saves them by killing a sixth. (Larry)

Case 3. Assassin A3 poisons five people. The poison proves insufficient to kill. (Stephen)

The usual approach to the moral luck problem is to compare Al with A3 (the assassin who hits versus the assassin who misses because he cannot help it), and to convince you that even though luck is all that separates the two, that is all right because you put up with luck in so many other domains of life.

My approach is different. It never asks you to directly compare Al with A3, and it does not draw on your uncertain intuitions about luck. Instead it asks you to compare $\mathrm{A} 1$ with $\mathrm{A} 2$ (the assassin who hits versus the assassin who turns his hit into a miss) and $\mathrm{A} 2$ with $\mathrm{A} 3$ (the assassin who turns his hit into a miss versus the assassin who misses because he cannot help it). Without having to appeal to your feelings about luck, I then tried to convince you that $A 1$ is worse than $A 2$ and that $A 2$ is worse than $A 3$, whence it followed that $A 1$ is worse than $A 3$. The case of $A 2$ thus plays the role of those poor starving children your mother liked to invoke. Thinking about it is supposed to make you feel differently about the familiar fare on your plate, the assassin who misses and the assassin who hits because he cannot help it.

\section{B. Objections}

Let me now deal with four objections to my argument. There are others, perhaps, but only these seem to pose a formidable challenge.

frustrated in his design by some external factor (the concoction process not coming off) rather than by doing something outrageous (the carving up of an innocent).

Larry Jr. in turn seems for the already familiar reasons better than Michael. (Michael planned to kill five and did. Larry only planned to kill one and did.) That implies that Stephen Jr. is better than Michael. That suggests that Stephen too is better than Michael, given how close Stephen and Stephen Jr. are to each other in blameworthiness. (The only way in which that could fail to be true is if Larry Jr. lies between Michael and Stephen Jr., but not between Michael and Stcphen. That in turn would mean that Larry Jr. lies between Stephen Jr. and Stephen. It is hard to see how or why that would be true, since we can bring Stephen Jr.'s and Stephen's blameworthiness as close to each other as we like by just bringing the moment at which Stephen Jr. encounters his frustrating external event as close to the point of injeetion as we like.) 
Objection \#1. "Hold on a second! Your argument keeps referring to this so-called moral ledger, which seems like a pretty consequentialist concept for a deontologist. Does this moral ledger really exist, and if so, who keeps it?"

Answer. The moral ledger is a shorthand for someone's overall blameworthmess. When someone has engaged in a course of conduct that includes numerous crimes, his overall blameworthmess is some function of the blameworthmess of those imdividual crimes. That is his moral ledgerhis total score taking into account all the wicked things he has done over a certain stretch of time. We routinely make assessments of overall blameworthiness. We do so when we ask ourselves who is worse, the person who has committed a rape and a murder, or the person who has committed two bank robberies in the course of which two bank employees unexpectedly died. We do so when we mete out punishment to someone who has been convicted of several crimes and want to make sure that he is not punished more harshly than he justly deserves. Sometimes we include praiseworthy actions in our assessment of someone's moral ledger: When we award prizes for humanitarian achievements, for mstance, or when we canonize a saint, or when we grant clenency to a reformed criminal.

It might seein a touch consequentialist to tote up the worth of someone's actions like that, and thus apparently inconsistent with being a deontologist. But that is not true. One has to carefully distinguish the different purposes for which a deontologist is toting up actions. A deontologist would not be willing to say that you should commit one murder now because you thereby avert several murders later on, on the ground that this would minimize the overall murder rate. But he is willing to say that someone who has committed several murders is worse than someone who has committed only one. If he were not willing to say that, he would have to give up on one of his principal tenets, namely the idea that criminals should be punished according to their deserts, and that different degrees of wrongdoing deserve different punishments.

Now I will not deny that there is something consequentialist about saying that two murders are worse than one. The fact that the deontologist is willing to be retrospectively consequentalist when evaluating someone, but is prospectively nonconsequentialist when telling people what they should do, is indeed at the root of my paradox. But this is something a deontologist cannot avoid doing. My answer to the next objection will shed further light on this. ${ }^{24}$

24. In his well-known article, Should the Numbers Count?, 6 PHIL. \& PUB. AFF. 293 (1977), John Taurek makes a surprisingly strong case for the proposition that a state of affairs in which five die cannot really be considered worse than a state of affairs in which one dies. If he is right, the logic of his argument might then also carry him to the conclusion that someone who commits five murders is no worse than someone who commits one, although it need not. In any event, a deontologist who is also a 
Objection \#2. "How can it be that doing the wrong thing improves your moral ledger? Should we not think that any argument that generates this conclusion has gone wrong somewhere?"

Answer. By no means, and the phenomenon is certainly not peculiar to this example. Indeed it follows directly from the key attribute of deontological morality, the impermissibility of certain kinds of tradeoffs, such as carving up one to save many, executing an innocent to appease a rabble threatening to kill several more, and torturing a child to find out where his father hid a bomb. In another article I present something I call the Gateway Sin Paradox to show how the fact of forbidden tradeoffs gives rise to this odd phenomenon. Let me just briefly recapitulate the argument I make there. ${ }^{25}$

The Gateway Sin Paradox involves a comparison of the blameworthiness of three characters whom I call Repentant Sinner, Bystander, and Strategic Sinner. Early on in life, Repentant Sinner has performed some wicked action; later on in life, he performs some great and heroic feats. Compare his moral ledger with that of Bystander who has neither sinned nor done anything great and heroic. Which of them is better? Given how few facts you have, you cannot really tell. But it should be clear that if the sin were modest enough and if the feats heroic enough, the Repentant Sinner might well come out ahead of the Bystander.

Let us turn next to my third character, Strategic Sinner. Strategic Sinner is confronted with the choice of embarking on one of two possible life-paths: He can either choose to live like Repentant Sinner, committing the same sin early in life and committing the same heroic acts later on, or he can choose to live like Bystander, exhibiting neither sin nor heroism. Those are his only two options. He chooses to sin and be a hero. How does Strategic Sinner's moral ledger compare with that of Repentant Sinner and Bystander? I would argue that he is no worse than, and probably better than, either of them. He certainly is not worse than Repentant Sinner, since he committed the same sin and the same heroic acts. He is arguably better than Repentant Sinner, because unlike Repentant Sinner he committed the sim only because it was his gateway to committing heroic acts later on. And if Strategic Sinner is no worse than Repentant Sinner, he certainly is better than Bystander (who is worse than Repentant Sinner).

We run into a paradox when we ask the question whether Strategic Sinner should have committed the "gateway sin." To see properly what is

retributivist certainly has to part company with Taurek, as have many of Taurek's respondents. See, e.g., 1 Frances KamM, Morality, Mortality 75-96 (1993); Derek Parfit, Innumerate Ethics, 7 PhIL. \& PUB. AFF. 285 (1978). Although I hate to disagree with ingeniously argued counterintuitive conclusions, this time I will.

25. See Leo Katz, Preempting Oneself: The Right and the Duty to Forestall One's Own Wrongdoing, 5 J. LEGAL THEORY 339 (1999). 
going on, let us make the situation more concrete. Let us assume the heroic deeds consisted of saving ten lives under truly frightful circumstances, demanding great effort, courage, and sacrifice. Let us assume the "gateway sin" consisted in the abuse, indeed the torture, of a child. And let us continue to assume that the saving of those ten lives is enough to make Repentant Sinner's moral ledger better than Bystander's, despite the earlier torture of a child. Does this mean that Strategic Sinner should be willing to torture a child so as to be able to save ten lives? Certainly not. Torturing a child in order to save several lives is the quintessential impermissible tradeoff. Torturing a child is therefore impermissible despite the fact that it would improve Strategic Sinner's moral ledger!

The Gateway Sin Paradox shows that situations in which doing the wrong thing improves one's overall moral position are a direct implication of two facets of deontological morality: (1) the impermissibility of certain tradeoffs, and (2) the fact that we assess someone's overall blameworthiness by aggregating his various and sundry wicked acts.

Objection \#3. "Your argument defending the law of attempt involved first showing that Larry (who kills a sixth to save the five) is better than Michael (who simply kills five) and then showing that Stephen (whose poison is too weak) is better than Larry. From the fact that Stephen is better than Larry and Larry better than Michael, you conclude that Stephen is better than Michael. That works if 'better than' is transitive, but is it? Some relations are transitive; others aren't. 'Taller than' is transitive: $A$ is taller than $B$, and $B$ is taller than $C$, it follows that $A$ is taller than $C$. But 'being the father of is not transitive: $A$ is the father of $B$, and $B$ is the father of $C$, but we cannot infer that $A$ is the father of $C$. How do you know that 'better than' (or 'less blameworthy than') works like 'taller than' rather than 'being the father of'?"

Answer. Some time ago I would have thought this an absolutely ridiculous objection. If $\mathrm{A}$ is less blameworthy than $\mathrm{B}$, and $\mathrm{B}$ is less blameworthy than $\mathrm{C}$, then obviously $\mathrm{A}$ is less blameworthy than $\mathrm{C}$. How could anyone possibly argue with that? But then I read Larry Temkin's article, $A$ Continuum Argument for Intransitivity, ${ }^{26}$ and now I am a little worried.

Temkin sets out to show that the relation "all things considered better than" is an imtransitive relation. Imagine, he says, someone who is suffering for several weeks from excruciating pain. Would it be better if instead of that, he were subjected to a slightly (but palpably) lesser pain for twice as long? No, it would be worse. Now compare this last possibilityslightly less pain for twice as long - with a third possibility: slightly less pain yet for twice as long again. That would be worse again. Now repeat

26. Larry S. Temkin, A Continuum Argument for Intransitivity, 25 PHIL. \& PuB. AFF. 175 (1996). 
the procedure: slightly lesser pain, twice as long again. Even worse. Keep going and eventually the pain to which we are subjecting someone-albeit for a very, very, very, very long time - is the equivalent of a hangnail. But that would suggest if "worse than" and "better than" are transitive, that having a hangnail for a very, very, very, very long time is worse than being tortured with excruciating pain for several weeks. And that seems absurd. Therefore, concludes Temkin, "better than" and "worse than" are not transitive.

The argument could easily be applied to blameworthiness just by adding a person who is inflicting the pain: Compare the criminal who subjects his victim to excruciating pain for several weeks to the criminal who subjects his victim to slightly (but palpably) less pain for twice as long, and compare him to the criminal who subjects his victim to slightly less pain yet, but for twice as long again. In each case it seems the criminal gets more and more blameworthy. But if we assume that "more blameworthy than" is transitive, then the criminal who subjects his victim to a life-long hangnail ${ }^{27}$ is worse than the criminal who tortures his victim for several weeks. And that seems absurd.

There is a lively literature on Temkin's problem. My guess is that most people do not agree with him, though they are having great trouble trying to prove him wrong. For my purposes, it suffices if I point out that accepting the intransitivity of blameworthiness is a far more radical move than accepting outcome luck and the law of attempt. (If blameworthiness were intransitive, that would render the idea of proportionate punishment incoherent. Not just indeterminate, but incoherent.) To reject the law of attempt on the ground that blameworthiness is intransitive would be a little like choosing to believe in UFOs rather than O.J. Simpson's innocence. The latter may be unlikely, but compared to the former?

Objection \#4. "One more thing. Let us go back briefly to Larry who tries to poison five and then tries to save them by carving up a sixth. Suppose that in trying to kill that sixth victim he fails. What is he now guilty of? Presumably, five murders (the five people he does not succeed in saving) and an attempted murder. Suppose in the alternative, that he succeeds. What is he guilty of then? Presumably, one murder and five attempts, a much better (that is, less immoral) score. So what we have here is a case in which attempting a crime gives you a worse moral score than completing that crime. How does this square with your argument in this essay that attempts are less wicked than completed offenses?"

Answer. You are perfectly correct. Sometimes an attempt affects one's moral position more adversely than completing the offense would.

27. At least if it is a really, supematurally long life. 
My claim that attempts are less wicked than completed offenses thus only holds generally true, but not invariably. It would be interesting to try to work out the exceptional circumstances under which this kind of reversal of the usual pattern can occur. Of course none of this offers much support for the luck-skeptic, who believes that attempts and completed offenses are equally wicked.

\section{CONCLUSION}

My defense of the law of attempt and the role of outcome luck has two distinct virtues. The first is that it does not appeal to intuitions about luck to justify intuitions about luck; instead, it relies on more basic, less contentious intuitions about coinparative blameworthiness.

The second is that it allows us to pinpoint where exactly the luckskeptic goes wrong, although I liave not made this explicit so far. What drives the luck-skeptic's skepticism about outcome luck is his intuition that events beyond one's control cannot influence one's moral position. More specifically, the luck-skeptic believes that only praiseworthy actions can improve one's moral ledger. Since the fact that the gunman's victim turned his head at the last minute is not a praiseworthy action on the part of the gunman, the luck-skeptic thinks that his moral score cannot be improved by that event.

But as my various paradoxes about moral score-keeping showed, the assessment of overall blameworthiness works in complicated ways. Sometimes one's moral position is harmed by praiseworthy actions; sometimes one's moral position is improved by blameworthy ones. Michael did the right, the praiseworthy, thing in not carving up a sixth victim to save his five earlier victims, but that only hurt his position. Larry did the wrong, the blameworthy, thing in carving up the sixth victim, but that only helped his. If even those actions that are blameworthy can improve the actor's moral score, then it is no longer unthinkable that events over which he has no control may nonetheless improve his moral position-like the flight of the bullet that has already left the barrel of his gun. The law of attempt is perverse. But it is the kind of perversity that is inherent in the process of moral score-keeping.

There is a special flttingness in my choosing to write about the law of attempt at this event in Sandy Kadish's honor. I recall having two epiphanies during my first year in law school. The first occurred when I realized that the best way to read the endless stream of questions with which casebook authors like to bombard students was to replace the question marks with periods and to preface each of the resulting sentences with the locution "Is it not strange that." My more important epiphany occurred when I read the chapter in Sandy's casebook devoted to mipossible attempts, his fictitious opinion about Lady Eldon's attempted smuggling of what she 
took to be French lace, and the hypothetical law review writer's rebuttal of the opinion with the help of Mr. Law and Mr. Fact. I suddenly thought I understood the distinctive nature of legal reasoning: It is not statutory parsing, it is not arguing about policy, and it is not the philosopher's quest for Truth and Justice, but rather . . . well, I have not quite figured out what it is, only that it is distinctive. But whenever I want to think of the clearest example of a distinctively legal set of arguments, I think of Lady Eldon and her French lace. 